\title{
PEMBELAJARAN MATEMATIKA DALAM PERSPEKTIF ALQURAN
}

\author{
Mulin Nu'man \\ Program Studi Pendidikan Matematika UIN Sunan Kalijaga Yogyakarta \\ mulin_numan@yahoo.com
}

\begin{abstract}
Abstrak
Al-Quran merupakan kitab suci umat Islam berisi pedoman hidup manusia. Sebagai pedoman hidup manusia, pasti di dalam alQuran tidak hanya memuat pedoman dalam beribadah saja, tetapi memuat pedoman hubungan antar manusia. Salah satu pedoman dalam hubungan antar manusia adalah pedoman yang mengatur cara menuntut ilmu termasuk di dalamnya adalah pembelajaran. Dalam artikel ini, akan disampaikan proses pembelajaran matematika dalam perspektif alQuran. Proses pembelajaran matematika dalam artikel ini merupakan tafsiran dari ayat-ayat alQuran yang dikaitkan dengan konsep pembelajaran matematika yang berkembang sekarang. Prinsip pembelajaran dalam alQuran adalah 1) kegiatan belajar tak dapat diwakili orang lain, harus dialami sendiri oleh siswa, 2) mengajar merupakan upaya untuk membuat orang lain belajar, 3) peran utama pengajar adalah menciptakan kondisi agar terjadi kegiatan belajar pada diri siswa, 4) pendekatan pembelajaran berpusat pada siswa, 5) saling berinteraksi, saling membantu, saling berbicara asyik dengan apa yang dikerjakan, dan 6) berbagi materi saling bertanya/ menjawab. Pembelajaran matematika dalam perspektif alQuran setidaknya memuat kegiatan-kegiatan sebagai berikut: 1) mengamati, membaca, berpikir (QS 96: 1-5), 2) tanya jawab (QS 55: 13), 3) percobaan (QS. 23: 12-16), 4) diskusi (QS 16: 125), 5) pemberian tugas/pembiasaan (QS 16: 67; QS 2: 219; QS: 4: 43; QS 5: 90), 6) pemecahan masalah (QS 94: 5-8), dan 7) refleksi (QS 2: 31-33).
\end{abstract}

Kata Kunci: Pembelajaran, Matematika, AlQuran

\section{PENDAHULUAN}

Sampai saat ini belum ada kesepakatan mengenai definisi matematika, beberapa ilmuwan yang mendefinisikan matematika di antaranya ialah Johnson dan Rising (1972) Matematika itu adalah pola berpikir, pola pengorganisasikan pembuktian yang logik; matematika itu adalah bahasa, bahasa yang menggunakan istilah yang didefinisikan dengan cermat, jelas, dan akurat, representasinya dengan simbul dan padat, lebih berupa bahasa simbul mengenai idea daripada mengenai bunyi; matematika adalah pengetahuan struktur yang terorganisasikan, sifat-sifat atau teori-teori itu dibuat secara deduktif berdasarkan kepada unsur-unsur yang didefinisikan atau tidak, aksioma-aksioma, sifat-sifat, atau teoriteori yang telah dibuktikan kebenarannya; matematika adalah ilmu tentang pola, keteraturan 
atau pola idea; dan, matematika itu adalah suatu seni, keindahannya terdapat pada keterurutan dan keharmonisannya (Ruseffendi, 1990: 2 )

Pembelajaran matematika menurut pandangan konstruktivis adalah memberikan kesempatan kepada siswa untuk mengkonstruksi konsep-konsep atau prinsip-prinsip matematika dengan kemampuan sendiri melalui proses internalisasi. Erman Suherman mengemukakan bahwa dalam pembelajaran matematika para siswa dibiasakan untuk memperoleh pemahaman melalui pengalaman tentang sifat-sifat yang dimiliki dan yang tidak dimiliki dari sekumpulan objek (Suherman, 1986: 55). Salah satu hakekat matematika adalah sifatnya akstrak, untuk itu seorang guru harus dapat menanamkan konsep matematika dengan baik agar siswa dapat membangun daya nalarnya secara logis, sistematik, konsisten, kritis, dan disiplin.

Sepercik harapan akan pembelajaran matematika di sekolah yang lebih baik dan bermutu terbesit di setiap guru khususnya para guru matematika. Sudah bukan zamannya lagi matematika menjadi momok yang menakutkan bagi siswa di sekolah. Jika selama ini matematika dianggap sebagai ilmu yang abstrak dan kering, teoretis dan hanya berisi rumusrumus, seolah berada "di luar"-mengawang jauh dan tidak bersinggungan dengan realitas kehidupan siswa-kini saatnya bagi siswa untuk akrab dan familier dengan matematika.

Belajar matematika sangat penting. Matematika merupakan induk dari seluruh cabang pengetahuan. Tony Buzan, penemu dan pengembang metode mind map, menganalogikan bahwa belajar matematika ibaratnya membangun rumah-rumahan dari kartu. Setiap kartu harus berada di tempatnya sebelum kartu berikutnya ditambahkan. Kalau ada kartu yang keliru letaknya atau salah satu saja kartu yang goyah maka seluruh bangunan rumah-rumahan tersebut akan roboh (Nurdiansah: 2010).

Berdasarkan analogi tersebut, mala pembelajaran di ruang kelas yang diaksanakan oleh guru harus kita perhatikan dengan seksama. Secara formal guru adalah orang yang pertama kali mengenalkan matematika kepada anak-anak. Cukup banyak anak-anak yang tidak pernah berhasil membangun rumah-rumahan kartu tersebut bahkan kewalahan di saat-saat awal mereka mengenal matematika karena guru tidak mampu menguatkan sekaligus mengutuhkan bagian-bagian dari rumah-rumahan kartu tersebut. Pembelajaran matematika harus memberi bekal anak untuk dapat membangun rumah dari kartu dengan baik.

Satu hal lagi yang sangat menarik bahwa matematika dalam kurun "zaman keemasan" para kaum Muslimin sekitar abad ke-delapan, adalah salah satu bidang ilmu yang paling digemari karena ada kaitannya dengan kebutuhan religi, misalnya untuk menghitung warisan dan kalender Islam, penentuan waktu shalat, menentukan waktu yang akurat dari gerakan bulan dan bintang, dan sebagainya. Sebagaimana diungkap oleh Mohaini Mohamed (dalam Nurdiansah: 2010) bahwa matematika menjadi kegemaran utama bagi kaum muslimin ketika itu karena bidang itu menggabungkan kesatuan dan karakter abstrak dari pemikiran Islam. 
Matematika tidak dianggap sebagai ajaran sekuler, tetapi lebih sebagai sarana untuk menyalurkan pemahaman pada bidang yang dapat dimengerti. Matematika, menurut kaum muslimin merupakan kunci menguak misteri tentang Tuhan.

Antusiasme relegius yang digambarkan diatas sekaligus menorehkan prinsip matematika dari sudut transendental bahwa Tuhan ada di segala tempat di alam semesta yang di dasarkan pada prinsip kepastian. Maka seperti yang dibukukan dalam sejarah, perkembangan dan produktivitas matematika terutama pada abad sembilan dan sepuluh seolah mengalami keajaiban yang luar biasa dikalangan matematikawan Islam. Belajar matematika adalah sesuatu yang cukup. Ini merupakan suatu syarat kecukupan karena dengan belajar matematika, kita akan belajar bernalar secara kritis, kreatif dan aktif. Sekaligus pada saat yang sama, kita akan mengamati keberdayaan matematika (power of mathematics) dan tentunya menumbuh kembangkan kemampuan learning to learn. Jadi, kecuali untuk mendapatkan daya matematika itu sendiri sebagai alat penyelesai permasalahan dalam kehidupan nyata, kita belajar matematika sebagai suatu wahana yang memfasilitasi kemampuan bernalar, berkomunikasi, dan peningkatan kepercayaan diri dalam bermatematika. Tentunya kemampuan bernalar yang dipunyai anak didik melalui proses belajar matematika itu akan meningkatkan pula kesiapannya untuk menjadi lifetime learner atau pemelajar sepanjang hayat.

Beberapa hal penting yang bisa diperoleh dari belajar matematika adalah:

1. Cara berpikir matematika itu sistematis, melalui urutan-urutan yang teratur dan tertentu. dengan belajar matematika, otak akan terbiasa untuk memecahkan masalah secara sistematis. Sehingga bila diterapkan dalam kehidupan nyata, matematika bisa membuat setiap masalah lebih mudah diselesaikan.

2. Cara berpikir matematika itu secara deduktif. Kesimpulan ditarik dari hal-hal yang bersifat umum, bukan dari hal-hal yang bersifat khusus. Sehingga akan terhindar dengan cara berpikir menarik kesimpulan secara "kebetulan".

3. Belajar matematika melatih menjadi manusia yang lebih teliti, cermat, dan tidak ceroboh dalam bertindak.

4. Belajar matematika juga mengajarkan menjadi orang yang sabar dalam menghadapi semua hal dalam hidup ini. Saat mengerjakan soal dalam matematika yang penyelesaiannya sangat panjang dan rumit, tentu harus bersabar dan tidak cepat putus asa. Jika ada langkah yang salah, coba untuk diteliti lagi dari awal. Jangan-jangan ada angka yang salah, jangan-jangan ada perhitungan yang salah. 
5. Banyak hal dalam kehidupan ini yang merupakan penerapan dari matematika. Misalnya, menghitung uang, laba dan rugi, masalah pemasaran barang, dalam teknik, bahkan hampir semua ilmu di dunia ini pasti menyentuh yang namanya matematika.

Secara historis dapat dipahami bahwa pada empat belas abad yang lalu diturunkan kitab suci Al-Qur'an. Sebelum Al-Qur'an turun, di dunia sudah terdapat banyak agama dan banyak kitab yang dianggap suci oleh penganut-penganutnya. Agama Kristen dengan kitab perjanjian lama dan kitab perjanjian baru. Selain agama Kristen, orang arab juga banyak menganut agama Yahudi. Di Negeri Arab hidup orang-orang Persia yang juga mempercayai seorang nabi dan sebuah kitab suci Zend Avesta. Kitab ini telah mengalami banyak perubahanperubahan oleh kelakuan tangan manusia akan tetapi masih banyak penganutnya. Di India, kitab Weda dan kitab Gita oleh Shri Krisna dan ajaran Budha. Agama Kong $\mathrm{Hu} \mathrm{Cu}$ menguasai Negeri Tiongkok akan tetapi pengaruh agama Budha lebih kuat dan makin meluas di negeri itu.

Al-Quran menggambarkan, ada 2 cara Allah SWT mengajar manusia, yaitu: 1) pengajaran langsung yang disebut wahyu/ilham dan 2) pengajaran tidak langsung. Cara yang terakhir ini berarti bahwa Allah mengajar manusia melalui media, yaitu fenomena alam yang Dia ciptakan. Allah menciptakan alam dan segala isinya serta hukum yang berlaku padanya. Alam menyimpan banyak rahasia ilmu pengetahuan. Tugas manusia untuk mempelajarinya sehingga menemukan sistem hukum alam tersebut yang selanjutnya dapat digunakan bagi kepentingan hidup manusia. Maka pekerjaan ilmuan hanya mencari dan menemukan hukum atau teori yang Allah telah tentukan berlaku pada alam, bukan menciptakan hukum atau teori tersebut. Inilah makna Allah mengajar manusia melalui alam dan segala isinya. Bagi kaum sekuler, ilmu itu dibentuk atas dasar fakta empiris atau indrawi tanpa menghiraukan sumbernya, yaitu Allah. Sedangkan dalam perspektif Islam, ilmu itu bersumber dari Allah, maka Dia menjadi pusat utama dalam pembelajaran dan penelitian. Mencari ilmu atau pengetahuan berarti mengkaji sifat-sifat Tuhan dan perbuatan-Nya yang terlukis pada sketsa alam, yang mesti disingkap oleh manusia dari berbagai rahasia alam.

Allah berfirman dalam AlQuran surat Al-Baqarah (2: 35) yang artinya "Mereka (Malaikat) menjawab: Maha Suci Engkau, tidak ada yang kami ketahui selain dari apa yang telah Engkau ajarkan kepada kami; sesungguhnya Engkaulah Yang Maha Mengetahui lagi Maha Bijaksana". Dalam ayat ini malaikat memberi pengakuan bahwa ilmu yang mereka peroleh hanya yang Allah ajarkan. Dalam kesempatan lain, Allah berfirman dalam surat arRahman (55: 32) yang artinya "Hai jama'ah jin dan manusia, jika kamu sanggup menembus (melintasi) penjuru langit dan bumi, maka lintasilah, kamu tidak dapat menembusnya kecuali dengan kekuatan (ilmu pengetahuan)".

Nabi Muhammad SAW bersabda yang artinya "barang siapa bertambah ilmu, namun tidak bertambah hidayah, maka tidaklah bertambah apapun kecuali bertambah jauh dari Allah 
SWT". Dari hadist tersebut tergambar jelas bahwa ilmu adalah hidayah. Demikian pula dalam surat Al-Baqarah ayat 185 menegaskan bahwa Al-Qur'an yang diturunkan berisikan petunjuk bagi manusia serta penjelasan tentang petunjuk tersebut. Selain itu, Al-Qur'an disamping berisikan petunjuk dan penjelasannya juga berisikan instrument dan alat ukur untuk membedakan antara yang benar dan yang salah, yang buruk dan yang baik.

Berdasarkan konsep fenomena di atas, dapat dipahami bahwa Al-Qur'an merupakan petunjuk dalam berbagai aspek kehidupan. Al-Qur'an tidak terbatas pada masalah keagamaan yang dogmatis saja tetapi juga masalah social, budaya, politik, ekonomi, maupun masalah pendidikan. Dengan demikian, bagaimana langkah-langkah pembelajaran matematika dalam perspektif alQuran?

\section{PEMBAHASAN}

Pada bagian ini penulis akan membahas ayat-ayat alQuran yang merupakan petunjuk bagi manusia dalam melaksanakan proses pembelajaran. Penulis sengaja memamaparkan makna dalam alQuran yang ada kaitannya dengan proses pembelajaran matematika karena pembelajaran matematika mempunyai ciri khusus. Proses pembelajaran matematika dalam artikel ini merupakan tafsiran dari ayat-ayat alQuran yang dikaitkan dengan konsep pembelajaran matematika yang berkembang sekarang.

Prinsip pembelajaran dalam alQuran adalah 1) kegiatan belajar tak dapat diwakili orang lain, harus dialami sendiri oleh siswa, 2) mengajar merupakan upaya untuk membuat orang lain belajar, 3) peran utama pengajar adalah menciptakan kondisi agar terjadi kegiatan belajar pada diri siswa, 4) pendekatan pembelajaran berpusat pada siswa, 5) saling berinteraksi, saling membantu, saling berbicara asyik dengan apa yang dikerjakan, dan 6) berbagi materi saling bertanya/ menjawab. Keenam prinsip tersebut harus menyatu dalam setiap proses pembelajaran termasuk pembelajaran matematika.

\section{Tahap-tahap Pembelajaran Matematika}

Pembelajaran matematika dalam perspektif alQuran setidaknya memuat kegiatan-kegiatan sebagai berikut:

\section{Membaca, Mengamati, Berpikir}

Membaca adalah perintah Allah pertama kepada Nabi Muhammad SAW. Membaca sangat penting dalam memperoleh ilmu pengetahuan. Perintah membaca memuat dua perintah sekaligus yaitu membaca dan menulis. Allah berfirman dalam surat Al-Alaq (96: 15) yang artinya "Bacalah dengan (menyebut) nama Tuhanmu Yang menciptakan, Dia telah menciptakan manusia dari segumpal darah, Bacalah, dan Tuhanmulah Yang Maha Pemurah, Yang mengajar (manusia) dengan perantaran kalam, Dia mengajar kepada manusia apa yang tidak diketahuinya". Ayat-ayat tersebut merupakan petunjuk bagi kita bahwa untuk mengetahui sesuati kita harus membaca. 
Menurut Buya Hamka dalam tafsir Al-Azhar "Dia yang mengajarkan dengan qalam." (ayat 4). Itulah keistimewaan Tuhan itu lagi. Itulah kemuliaan-Nya yang tertinggi. Yaitu diajarkan-Nya kepada manusia berbagai ilmu, dibuka-Nya berbagai rahasia, diserahkan-Nya berbagai kunci untuk pembuka perbendaharaan Allah, yaitu dengan qalam. Dengan pena, di samping lidah untuk membaca, Tuhan pun mentakdirkan pula bahwa dengan pena ilmu pengetahuan dapat dicatat. Pena adalah beku dan kaku, tidak hidup, namun yang dituliskan oleh pena itu adalah berbagai hal yang dapat difahamkan oleh manusia "Mengajari manusia apa-apa yang dia tidak tahu." (ayat 5). Lebih dahulu Allah Ta'ala mengajar manusia mempergunakan qalam. Sesudah dia pandai mempergunakan qalam itu banyaklah ilmu pengetahuan diberikan oleh Allah kepadanya, sehingga dapat pula dicatatnya ilmu yang baru didapatnya itu dengan qalam yang telah ada dalam tangannya: "Ilmu pengetahuan adalah laksana binatang buruan dan penulisan adalah tali pengikat buruan itu. Oleh sebab itu ikatlah buruanmu dengan tali yang teguh."

Membaca di sini tidak hanya membaca ayat-ayat yang tertulis, tetapi membaca juga ayat-ayat tidak tertulis yaitu alam. Membaca alam dalam hal ini disebut dengan mengamati. Mengamati objek matematika sangat penting dalam belajar matematika. Mengamati tidak hanya melibatkan panca indra mata tetapi juga melibatkan otak atau kita sebut berpikir. Kegiatan membaca, mengamati, dan berpikir merupakan satu kesatuan dalam mengawali proses pembelajaran matematika.

Hal ini senada dengan langkah-langkah pembelajaran pendekatan saintifik yang pertama yaitu mengamati. Mengamati dapat dilakukan antara lain melalui kegiatan mencari informasi, melihat, mendengar, membaca, dan atau menyimak. Contoh kegiatan membaca adalah membaca surat pendek dalam alQuran kemudian siswa diminta menghitung frekuensi huruf alif, wawu, dan ya sekaligus membuat diagramnya. Contoh kegiatan mengamati adalah mengamati gambar berbagai macam segitiga dan meminta siswa berpikir tentang definisi segitiga siku-siku dilihat dari panjang sisi-sisinya.

\section{Tanya Jawab}

Kegiatan tanya jawab merupakan kegiatan yang sangat penting dalam pembelajaran matematika. Ilmu pengetahuan dalam hal ini teori selalu dibangun dari suatu pertanyaan. Dari pertanyaan, seseorang akan melakukan aktivitas penyelidikan dan pencarian untuk memperoleh suatu jawaban (teori).

Allah SWT dalam beberapa kesempatan memulai surat dengan suatu pertanyaan yang kemudian dijawab di ayat lainnya. Misalnya surat al-Maaun (107: 1-7), Allah menjelaskan sifat-sifat orang yang mendustakan agama dengan suatu pertanyaan pada ayat 1 yang artinya "tahukah kamu (orang) yang mendustakan agama?" dan menjawab pertanyaan tersebut pada ayat selanjutnya. Dalam surat ar-Rahman (55: 13) Allah SWT menyampaikan suatu pertanyaan yaitu "maka nikmat Tuhan kamu yang manakah yang kamu dustakan?". Ayat serupa dinyatakan berulang-ulang oleh Allah pada ayat-ayat selanjutnya. Hal ini jelas 
menggambarkan bahwa dalam perspektif AlQuran, tanya jawab sangat penting dalam proses pembelajaran matematika.

Hal ini senada dengan pendapat ahli pembelajaran saat ini, misalnya dalam pendekatan Saintifik, langkah kedua setelah mengamati adalah bertanya. Dalam model pembelajaran berbasis penemuan (inquiry based learning), problem based learning, maupun project based learning selalu diawali dengan mengajukan pertanyaan.

Beberapa ciri pertanyaan dalam pembelajaran yang baik menurut alQuran adalah 1) pertanyaan tersebut harus ada jawabannya, 2) pertanyaan tersebut fokus pada teori yang hendak dituju, 3) pertanyaan berupa penyelidikan (proses berpikir), dan 4) pertanyaan ditujukan pada semua siswa atau dengan kata lain semua bisa menjawab pertanyaan tersebut.

\section{Percobaan}

Percobaan merupakan kegiatan penyelidikan untuk membuktikan suatu hipotesis atau teori. Dalam pembelajaran dengan pendekatan saintifik percobaan merupakan tahap pembelajaran ketiga. Kegiatan percobaan sangat penting karena siswa perlu mengalami sendiri ilmu pengetahuan agar ilmu tersebut masuk ke dalam memori jangka panjang. Ausubel (1987) mengatakan belajar bermakna akan terjadi bila si pembelajar dapat mengaitkan informasi yang baru diperolehnya dengan konsep-konsep (dikenal sebagai subsumer-subsumer) relevan yang terdapat dalam struktur kognitif siswa tersebut. Salah satu cara agar pembelajaran itu bermakna adalah belajar dengan mengalami sendiri (percobaan).

Allah berfirman dalam surat al-Mu'minun (23: 12-16) yang artinya "Dan sesungguhnya Kami telah menciptakan manusia dari suatu saripati (berasal) dari tanah. Kemudian Kami jadikan saripati itu air mani (yang disimpan) dalam tempat yang kokoh (rahim). Kemudian air mani itu Kami jadikan segumpal darah, lalu segumpal darah itu Kami jadikan segumpal daging, dan segumpal daging itu Kami jadikan tulang belulang, lalu tulang belulang itu Kami bungkus dengan daging. Kemudian Kami jadikan dia makhluk yang (berbentuk) lain. Maka Maha sucilah Allah, Pencipta Yang Paling Baik. Kemudian, sesudah itu, sesungguhnya kamu sekalian benar-benar akan mati. Kemudian, sesungguhnya kamu sekalian akan dibangkitkan (dari kuburmu) di hari kiamat".

Ayat tersebut menjelaskan proses kehidupan manusia dari proses penciptaan sampai kematian dan kebangkitan. Ayat ini kemudian membuat ilmuan melakukan banyak percobaan (eksperimen) yang akhirnya melahirkan banyak teori.

\section{Diskusi}

Allah berfirman dalam surat an-Nahl (16: 125) yang artinya "Serulah (manusia) kepada jalan Tuhan-mu dengan hikmah (perkataan yang tegas dan benar yang dapat membedakan antara yang hak dengan yang bathil) dan pelajaran yang baik dan bantahlah mereka dengan cara yang baik. Sesungguhnya Tuhanmu Dialah yang lebih mengetahui tentang siapa yang tersesat dari jalan-Nya dan Dialah yang lebih mengetahui orang-orang yang mendapat petunjuk". Ayat ini jelas bahwa pengetahuan dapat diperoleh dengan berbantahan (diskusi) 
dengan cara yang baik. Diskusi yang baik adalah diskusi yang memungkinkan adanya tukar menukar pengetahuan dengan tanpa menekan dan memaksa seseorang untuk merasa salah atau tidak benar. Diskusi yang baik dalam bahasa pembelajaran adalah diskusi yang terdapat saling ketergantungan positif di antara peserta diskusi.

Dalam berbagai literatur terbukti bahwa pembelajaran yang memuat unsur diskusi jauh lebih baik dibanding dengan pembelajaran searah. Diskusi bisa dilakukan oleh guru dengan siswa atau siswa dengan siswa. Diskusi akan berjalan dengan baik dan terarah jika ada bahan diskusi (pertanyaan diskusi). Dalam diskusi, guru berperan sebagai fasilitator kegiatan diskusi dengan menyediakan pertanyaan diskusi dan mengarahkan jalannya diskusi agar berjalan dengan baik (wajadilhum billatii hiya ahsan). Pertanyaan diskusi bisa dalam bentuk LKS (lembar kerja siswa) atau LAS (lembar aktivitas siswa).

\section{Pemberian Tugas/Pembiasaaan}

Kegiatan pembelajaran matematika selanjutnya adalah pemberian tugas. Pemberian tugas dilakukan dalam rangka membiasakan siswa dalam berpikir matematis dalam menyelesaikan masalah. Pembiasaan bisa berdampak pada kebermaknaan belajar atau kuatnya pengetahuan menancap di memori siswa dan perilakunya.

Allah SWT menjelaskan betapa pembiasaan itu sangat berdampak pada kuatnya pengetahuan tertancap di otak. Misalnya pada surat an-Nahl (16: 67) Allah berfirman yang artinya "Dan dari buah korma dan anggur, kamu buat minuman yang memabukkan dan rezki yang baik. Sesunggguhnya pada yang demikian itu benar-benar terdapat tanda (kebesaran Allah) bagi orang yang memikirkan"; kemudian firman Allah pada surat al-Baqarah (2: 219) yang artinya "Mereka bertanya kepadamu tentang khamar dan judi. Katakanlah: Pada keduanya terdapat dosa yang besar dan beberapa manfaat bagi manusia, tetapi dosa keduanya lebih besar dari manfaatnya. Dan mereka bertanya kepadamu apa yang mereka nafkahkan. Katakanlah: Yang lebih dari keperluan. Demikianlah Allah menerangkan ayatayat-Nya kepadamu supaya kamu berfikir"; kemudian firman Allah pada surat an-Nisa (4: 43) yang artinya "Hai orang-orang yang beriman, janganlah kamu shalat, sedang kamu dalam keadaan mabuk, sehingga kamu mengerti apa yang kamu ucapkan, (jangan pula hampiri mesjid) sedang kamu dalam keadaan junub, terkecuali sekedar berlalu saja, hingga kamu mandi. Dan jika kamu sakit atau sedang dalam musafir atau datang dari tempat buang air atau kamu telah menyentuh perempuan, kemudian kamu tidak mendapat air, maka bertayamumlah kamu dengan tanah yang baik (suci); sapulah mukamu dan tanganmu. Sesungguhnya Allah Maha Pema'af lagi Maha Pengampun"; dan firman Allah surat Ali Imron (5: 90) yang artinya "Hai orang-orang yang beriman, sesungguhnya (meminum) khamar, berjudi, (berkorban untuk) berhala, mengundi nasib dengan panah, adalah termasuk perbuatan syaitan. Maka jauhilah perbuatan-perbuatan itu agar kamu mendapat keberuntungan".

Serangkaian ayat di atas merupakan gambaran bahwa jika minum minuman yang memabukkan itu dibiasakan akan berdampak tidak baik. Hal ini bisa dibuat kontraposisinya, 
jika ingin dampak yang baik, maka siswa harus dibiasakan melakukan kebaikan. Jika ingin siswa mengingat konsep matematika maka biasakan siswa mengerjakan tugas matematika.

\section{Pemecahan Masalah}

Memecahkan suatu masalah merupakan suatu aktivitas dasar bagi manusia. Kenyataan menunjukkan, sebagian besar kehidupan kita adalah berhadapan dengan masalah-masalah. Kita perlu mencari penyelesaiannya. Bila kita gagal dengan suatu cara untuk menyelesaikan suatu masalah. Kita harus mencoba menyelesaiakannya dengan cara lain. Kita harus berani menghadapi masalah untuk menyelesaiakannya.

Allah berfirman dalam surat al-Insyirah (94: 5-8), yang artinya "Karena sesungguhnya sesudah kesulitan itu ada kemudahan. sesungguhnya sesudah kesulitan itu ada kemudahan. Maka apabila kamu telah selesai (dari sesuatu urusan), kerjakanlah dengan sungguhsungguh (urusan) yang lain. dan hanya kepada Tuhanmulah hendaknya kamu berharap". Ayat ini menggambarkan bahwa setiap usaha manusia selalu ada kemudahan yang mengikuti suatu kesulitan seseorang. Menurut Nauvila (2009: ix) Al-Quran telah menjelaskan tentang kehidupan masyarakat, dalam alQuran seseorang yang mempunyai masalah yang besar, janganlah masalah itu dianggap sebuah cobaan, akan tetapi dianggap sebagai nikmat sebagaimana telah disebutkan dalam surah Al-Insyirah. Allah memberi masalah agar manusia mendapatkan nikmat.

Kaitan ayat ini dengan pembelajaran matematika adalah jika mau mendapatkan hasil yang baik (kenikmatan), siswa harus diberikan suatu masalah untuk diselesaikan. Masalah di sini bukan dibuat untuk menyengsarakan siswa tetapi melatih siswa agar berhasil dalam belajar. Menurut Hudojo, H. (2003: 19) suatu pertanyaan akan merupakan suatu masalah hanya jika seseorang tidak mempunyai aturan/hukum tertentu yang segera dapat dipergunakan untuk menemukan jawaban pertanyaan tersebut. Pertanyaan itu dapat juga terselinap dalam suatu situasi sedemikian hingga situasi itu sendiri perlu mendapat penyelesaian. Karena itu kegiatan memecahkan masalah harus merupakan kegiatan yang harus ada dalam setiap kegiatan pembelajaran matematika.

\section{Refleksi}

Refleksi dalam pembelajaran merupakan kegiatan yang sangat penting. Refleksi adalah kegiatan bertanya pada siswa tentang bagaimana pemahaman terhadap konsep-konsep matematika yang dipelajari hari ini. Hasil refleksi bisa dijadikan guru sebagai evaluasi terhadap proses pembelajaran yang dilakukan. Dalam alQuran kegiatan refleksi digambarkan dalam surat al-Baqarah (2: 31-33) yang artinya "Dan Dia mengajarkan kepada Adam namanama (benda-benda) seluruhnya, kemudian mengemukakannya kepada para Malaikat lalu berfirman: Sebutkanlah kepada-Ku nama benda-benda itu jika kamu mamang benar orangorang yang benar. Mereka menjawab: Maha Suci Engkau, tidak ada yang kami ketahui selain dari apa yang telah Engkau ajarkan kepada kami; sesungguhnya Engkaulah Yang Maha Mengetahui lagi Maha Bijaksana. Allah berfirman: Hai Adam, beritahukanlah kepada 
mereka nama-nama benda ini. Maka setelah diberitahukannya kepada mereka nama-nama benda itu, Allah berfirman: Bukankah sudah Ku katakan kepadamu, bahwa sesungguhnya Aku mengetahui rahasia langit dan bumi dan mengetahui apa yang kamu lahirkan dan apa yang kamu sembunyikan?.

Pada ayat di atas terdapat beberapa aspek penting yaitu a) pengajaran dari Allah SWT kepada Nabi Adam As. Allah sebagai pendidik, dan Nabi Adam sebagai peserta didik, b) aspek bahan ajar, yaitu nama-nama benda seluruhnya yang ada di alam raya ini, c) bentuk umpan balik (refleksi), yaitu perintah Allah kepada Adam agar menginformasikan kembali ilmu yang pernah diajarkan kepadanya di hadapan para Malaikat. Ini mirip seperti ujian plus asistensi, dan d) aspek hasil umpan balik dalam bentuk penguasaan Nabi Adam secara prima terhadap pengetahuan yag telah diajarkan Allah kepadanya.

\section{SIMPULAN DAN SARAN}

Pembelajaran matematika dalam perspektif alQuran setidaknya memuat kegiatankegiatan sebagai berikut: 1) mengamati, membaca, berpikir (QS 96: 1-5), 2) tanya jawab (QS 55: 13), 3) percobaan (QS. 23: 12-16), 4) diskusi (QS 16: 125), 5) pemberian tugas/pembiasaan (QS 16: 67; QS 2: 219; QS: 4: 43; QS 5: 90), 6) pemecahan masalah (QS 94: 5-8), dan 7) refleksi (QS 2: 31-33).

Kegiatan tersebut tidak mutlak harus ada semua dalam setiap kegiatan pembelajaran matematika. Guru bisa memilih beberapa kegiatan yang cocok dengan materi matematika yang akan dibahas dalam kelas. Untuk mengetahui kombinasi yang paling bagus dari kegiatan-kegiatan tersebut perlu dilakukan penelitian lebih lanjut.

\section{DAFTAR RUJUKAN}

Abdi, Ali. 2014. The Effect of Inquiry-based Learning Method on Students' Academic Achievement in Science Course. Universal Journal of Educational Research 01: 37-41

Amrullah, AMAK. 1999. Tafsir al-Azhar Jilid 6. Jakarta: Pustaka Nasional

Ausubel, D., Novak, J., \& Hanesian, H. 1978. Educational Psychology: A Cognitive View (2nd Ed.). New York: Holt, Rinehart \& Winston)

Departemen Agama RI., 1985. AlQur'an dan Terjemahnya, Jakarta: Proyek Pengadaan Kitab Suci Al-Qur'an.

Hudojo, H. 2003. Pengembangan Kurikulum dan Pembelajaran Matematika. JICA. Jakarta: IMSTEP.

Kemendikbud. 2013. Konsep Pendekatan Saintifik (ppt). Disajikan dalam Pelatihan Kurikulum 2013. IKIP PGRI Semarang, 30 Juli 2013. 2013. Permendikbud No 65 Tahun 2013. Jakarta: Kemendikbud

Muslich, M. 2007. KTSP Pembelajaran Berbasis Kompetensi dan Kontekstual. Jakarta: Bumi Aksara

Nauvilla, I. 2009. Surah al-Insyirah dan Pemecahan Masalah. Skripsi. Yogyakarta: UIN Sunan Kalijaga Yogyakarta

Nurdiansah, A. 2010. Pentingnya Belajar Matematika. http://andinurdiansah.blogspot.co.id/2010/10/pentingnya-belajar-matematika.html 
Ruseffendi. 1990. Pengajaran Matematika Modern dan Masa Kini. Bandung: Tarsito

Rusmono. 2012. Strategi Pembelajaran dengan Problem Based Learning Itu Perlu. Bogor: Ghalia Indonesia

Suherman, E. 1986. Strategi Belajar Mengajar Matematika. Jakarta Dirjen Dikdasmen Depdikbud 